\title{
\#Stillnotfound: Missing Children in South Africa
}

\author{
Monique Emser \\ Marcel van der Watt
}

\section{Abstract}

In the year following South Africa's first inclusive democratic national elections, Nelson Mandela (1995) famously proclaimed that: 'There can be no keener revelation of a society's soul than the way in which it treats its children.' As a new democracy, South Africa has had to grapple with high levels of interpersonal violence attributed to post-conflict societies. Harris (n.d.) suggests that ' $[w]$ hile the past still impacts on present forms of violence, new trends, targets and perpetrators have also emerged within South Africa's democratic-era (some in direct response to democratisation itself).' Unfortunately, children are often its silent victims. Despite expansive child protection laws, which seem to have had little impact on the prevalence of crimes committed against them and by them, children remain objects of exclusion. Hsiao et al. (2018) found that while children were disproportionately affected by high levels of violence, political and financial investment to address this remained low. Much violence against children remains unreported and unrecorded (Optimus Study 2016), due in part to the culture of silence that pervades our society. Using the recent spate of child abductions and missing children cases, which have caught popular attention and sparked moral outrage, we examine the issue of missing children in South Africa within the wider phenomenological framework of violence against children. Over the past 18 years, approximately 16000 children have been reported missing. 25 percent of these children have never been found. This does not include the number of cases that are not reported to authorities. While statistics only provide a snapshot of the problem, we interrogate the cases of the 'missing' missing using data from our own research, Missing Children South Africa and the South African Police Service. Using an interpretive approach, we reflect on our lived experiences working in a network of state 
and civil society stakeholders engaging with such cases. We conclude that missing children cases are intricately intertwined with the layers of violence that have become embedded in South African society in the democratic era. We offer a series of policy recommendations to address this complex issue.

Keywords: missing children, violence against children, abductions, kidnappings, human trafficking, interpersonal violence, structural violence, child protection

\section{Introduction}

Despite celebrating its $25^{\text {th }}$ year of democracy, South Africa continues to grapple with a legacy of violence and trauma attributed to post-conflict societies. Numerous examples abound in the literature on political violence and armed conflict that affected countries like Angola, the Democratic Republic of Congo, Liberia, Sierra Leone and the Former Yugoslavia (Wessels 2008; Mujawayo 2014; Kabwete 2018; Kadir, Shenoda, Goldghagen \& Pitterman, et al. 2018). Wessels (2008) notes six salient features of conflict in the African region whose legacy plays a significant role in post-conflict societies:

(i) the protracted nature of the conflict;

(ii) (ii) structural violence - linked to socio-economic inequities and political oppression;

(iii) conflict grounded in poverty, weak governance, and fragile political and economic systems;

(iv) a lack of social cohesion and a fractured civil society;

(v) the use of generalised terminology which does not capture the diversity of such conflicts; and

(vi) rape and other forms of gender-based violence.

Violent crime, particularly interpersonal violence against women and children, remain normative in South African society (Hamber \& Lewis 1997; Sibanda-Moyo, Khonje \& Brobbey 2017; South African Human Rights Commission 2018). The world report on violence and health (WHO - VPA) defines violence as: 'the intentional use of physical force or power, threatened or actual, against oneself, another person, or against a group or community, that either results in or has a high likelihood of resulting in injury, death, 
psychological harm, maldevelopment, or deprivation'. Harris (n.d.) suggests that '[w]hile the past still impacts on present forms of violence, new trends, targets and perpetrators have also emerged within South Africa's democraticera (some in direct response to democratisation itself)'. In the post-Apartheid era, a neglected field of study is that of missing persons - particularly missing children.

Approximately $35 \%$ of South Africa's population are children (Hall \& Sambu 2017). Sibanda (2019) notes that this represents a 'relatively large contingent of vulnerable individuals who often have to rely on others for access to basic and fundamental human rights'. As a heterogeneous group, children may simultaneously experience multiple threats to their human rights (ibid.), of which poverty and gender-based violence are major drivers. The United Nations Convention on the Rights of the Child (General Assembly resolution $44 / 25$ of 20 November 1989) and the African Charter on the Rights and Welfare of the Child (OAU Doc. CAB/LEG/24.9/49 1990) have been used as guiding international agreements for the development and transformation of law and policy relating to children in South Africa. Applicable legislation and policy include, inter alia, the Constitution of the Republic of South Africa (1996), the White Paper for Social Welfare (1997), the Children's Act (38 of 2005 as amended), the Criminal Law (Sexual Offences and Related Matters) Amendment Act (32 of 2007), the Child Justice Act (75 of 2008), the Prevention and Combating of Trafficking in Persons Act (7 of 2013), the Film and Publications Amendment Act (11 of 2019), National Plan of Action for Children 2012-2017, Phase IV (2017-2021) of the Child Labour Programme of Action for South Africa, and the National Policy Framework on Trafficking in Persons (2019). 'While well-conceived child protection systems exist, very limited data is available to determine the extent of their effectiveness' (EPACT 2019:3). A lack of effective implementation is attributed to a lack of political will, resource allocation, and a continued reactive approach to child protection in terms of programme landscape and approaches resulting in child protection systems remaining unintegrated (van Niekerk n.d.; Makoae 2014).

Despite South Africa's expansive child protection laws that meet international norms and standards, they seem to have had little impact on the prevalence of crimes committed against them and by them. Children remain objects of exclusion. Hsiao et al. (2018) found that while children were disproportionately affected by high levels of violence, political and financial investment to address this remained low. Much violence against children 
remains unreported and unrecorded (Optimus Study 2016), due in part to the culture of silence that pervades our society. Using the recent spate of child abductions and missing children cases, which have caught popular attention and sparked moral outrage, we examine the issue of missing children in South Africa within the wider phenomenological framework of violence against children. An interpretive phenomenological approach allows for a rich, detailed description of lived experiences rather than producing an account prescribed by pre-existing theoretical preconceptions (Vujovic 2008; Smith \& Osborne 2015). Over the past 18 years, approximately 16000 children have been reported missing. 25 percent of these children have never been found. This does not include the number of cases that are not reported to authorities. While statistics only provide a snapshot of the problem, we interrogate the cases of the 'missing' missing using data from our own research, Missing Children South Africa and the South African Police Service. Using an interpretive approach, we reflect on our lived experiences working in a network of state and civil society stakeholders engaging with such cases. We conclude that missing children cases are intricately intertwined with the layers of violence that have become embedded in South African society in the democratic era. We offer a series of policy recommendations to address this complex issue.

\section{Democratisation and the Legacy of Violence in post- Apartheid South Africa}

South Africa continues to struggle with high levels of violence, despite a relatively peaceful transition to democracy 25 years ago and the introduction of an inclusive democratic dispensation. For a country not at war, South Africa has unacceptably high levels of morbidity and mortality linked to violence and injury (Seedat, van Niekerk, Jewkes, Suffla \& Ratele 2009). Oft cited are the legacy of apartheid and the inculcation of violence (CVSR 2009). Violence in post-apartheid South Africa is a multifaceted process with social, cultural and political dimensions. Kynoch (2005:493) suggests that the criminal dimensions of political conflict that occurred in South Africa in the 1980s and 1990s are key to understanding why the advent of democracy was not 'sufficient to erase a deeply entrenched culture of violence produced by decades of repressive racial policing, violent crime and social conflict'. Harris (2003) claims that mistrust, suspicion, and fear continue to define many interpersonal relation- 
ships. 'Living in the midst of violence transforms citizens' perceptions of their physical and political environment. This takes various forms, but in the long run can weaken commitment to democracy and encourage people to support forms of authority which guarantee stability of sorts, although backed by threat and coercion' (Pearce, McGee \& Wheeler 2011:13). Interpersonal violence refers to 'violence between family members and intimates, and violence between acquaintances and strangers that is not intended to further the aims of any formally defined group or cause' (World Health Organization 2004:2). Scheper-Hughes and Bourgois (2004:2) note that 'everyday violence' is generally a less visible form of violence and far more insidious than overt or interpersonal violence as it 'destroys a socially marginalized human with even greater frequency'. South Africa has often been referred to as one of the world's most unequal societies which has resulted in multi-layered threats to children and their access to basic human rights and justice. Poverty, urban migration, poor living conditions, poor policing, high levels of crime, genderbased violence and the absence of parents from children's daily lives have been cited as threats to children's well-being (Social Trends Institute 2017; Hall \& Sambu 2018; Sibanda 2019). Children are especially vulnerable to interpersonal violence and other forms of maltreatment in South Africa.

South Africa has 'a fragmented, inadequate system which is failing our children daily. Perpetrators aren't brought to justice, and children don't receive crucial therapeutic and support services that are vital to their recovery and long-term well-being' (Barnard quoted by Nxumalo \& Philander 2017). This is supported by evidence from the Optimus Study (2016: 15) which shows that:

In South Africa, particular risk for child maltreatment is also inherent in a poorly functioning police service and criminal justice system (Richter 2003). Combined with an overwhelmed social development service, this means that cases of child maltreatment end up unreported, delayed, or re-prioritised over cases deemed more serious in nature. Other cases go uninvestigated or abruptly dismissed by the criminal justice process. In most instances, maltreatment is considered a 'child welfare' issue and redirected to social development services. Perpetrators of maltreatment are rarely held accountable for their actions and, as a result, children remain vulnerable to further abuse and maltreatment, unchecked by the system. 
This has serious implications for the way missing children cases are recorded or dealt with, as discussed later in this article. In many instances, children who go missing have been viewed as 'runaways' or 'tearaways', problem children who will return on their own. However, in recent years with the rise in awareness of human trafficking and high profile abduction cases, and the evergrowing reality that children make up a significant proportion of victims of crime, missing children cases have gained more traction and public attention. A number of non-governmental organisations, such as Missing Children South Africa, deal with the increasing spate of missing children and persons' cases. The prevalence of violence against children in South Africa is unsettling and points to wider societal issues. For instance, South Africa's child homicide rate is twice the global average and every day 51 cases of child sexual abuse are reported (Hsiao et al. 2018; Optimus Study 2016). The Optimus Study (2016) found that one in five children $(19.8 \%)$ experienced sexual abuse, one in three (34.4\%) experienced physical abuse, one in six (16.1\%) reported experiencing emotional abuse, one in eight $(12.2 \%)$ reported being neglected and one in six (16.9\%) reported witnessing violence. In terms of physical and sexual abuse, South African children experience more violence compared to the global average (Hsiao et al. 2018; Optimus Study, 2016). In a separate study, Mathews, Govender and Lamb et al. (2016) found children were at highest risk of violence:

(i) when living in households where neither parent is present;

(ii) where financial resources were scarce; and

(iii) where they were exposed to drugs, alcohol, crime and conflict within the community.

'Children who experience violence are more likely to use drugs, suffer from depression, or become violent themselves, perpetuating a devastating cycle' (Gould 2018). Violence against children 'takes several forms within a general definition, different forms of violence frequently occur together, and violence occurs in all settings in which children find themselves - at home, in school, in the community and among peers, as well as more recently in cyberspace' (Richter, Mathews, Kagura \& Nonterah 2018:182). However, most of the literature on violence against children and child protection in South Africa fail to account how this may result in children going missing, or consider missing children as part of the cycle of violence against children. 


\section{Definitions and Legislative Framework}

There is no international legal definition of a missing child. Neither is there a global strategy. Instead there are generic international child protection instruments: the Hague Convention on the Civil Aspects of International Child Abduction $(1980)^{1}$, the United Nations Convention on the Rights of the Child $(1989)^{2}$, the Optional Protocol to the United Nations Convention on the Rights of the Child on the Sale of Children, Child Prostitution and Child Pornography $(2000)^{3}$, the Protocol to Prevent, Suppress and Punish Trafficking in Persons Especially Women and Children (2000) $)^{4}$, the Optional Protocol to the United Nations Convention on the Rights of the Child on the Involvement of Children in Armed Conflict (2000), the United Nations International Convention for the Protection of All Persons from Enforced Disappearance (2000) $)^{5}$. In terms of domestic legislation, the Children's Act 38 of 2005 is silent on missing children as a category in and of itself, but refer to separate incidents where a child may go missing by abduction by a parent (see Chapter 17, section 275 of the Act). Similarly, in relation to trafficking in persons, the National Policy Framework does not consider the multi-layered nature of vulnerability, particularly where children are concerned. Generic categorisations such as 'being a child' or 'socio-economic circumstances' provide little insight for implementing departments or agencies. For the purposes of this study, a 'missing child' is defined as 'any person under the age of 18 whose whereabouts are unknown' (ICMEC n.d.). 'The term 'missing person' acquires an objective meaning when a person is formally reported as missing, or when an unidentified body is discovered' (ibid.) There are a host of reasons why a child may go missing. One that practitioners in the field are increasingly aware

${ }^{1} 25$ October 1980, T.I.A.S. No. 11670, 1343 U.N.T.S. 98.

${ }^{2}$ G.A. Res. 44/25, U.N. GAOR 61st plen. mtg. at 166, U.N. Doc. A/44/736 (1989). The Convention on the Rights of the Child defines 'child' as 'every human being below the age of eighteen years unless under the law applicable to the child, majority is attained earlier'.

${ }^{3}$ G.A Res. 54/263, Annex II, U.N. Doc. A/54/49, Vol. III, art. 2, para. C, entered into force 18 January 2002.

${ }^{4}$ G.A. Res. A/RES/55/25, Nov. 15, 2000, entered into force on 25 December 2003.

${ }^{5}$ G.A. Res. A/RES/54/263 (May 25, 2000), entered into force 12 February 2002. 
of is human trafficking. We maintain that there is a growing nexus between missing persons and human trafficking. Trafficking in persons is defined in the Prevention and Combating of Trafficking in Persons Act 7 of 2013 as '(1) Any person who delivers, recruits, transports, transfers, harbours, sells, exchanges, leases or receives another person within or across the borders of the Republic, by means of-

(a) a threat of harm;

(b) the threat or use of force or other forms of coercion;

(c) the abuse of vulnerability;

(d) fraud;

(e) deception;

(f) abduction;

(g) kidnapping;

(h) the abuse of power;

(i) the direct or indirect giving or receiving of payments or benefits to obtain the consent of a person having control or authority over another person; or

(j) the direct or indirect giving or receiving of payments, compensation, rewards, benefits or any other advantage, aimed at either the person or an immediate family member of that person or any other person in close relationship to that person, for the purpose of any form or manner of exploitation, is guilty of the offence of trafficking in persons'.

Children are particularly vulnerable to being exploited for sexual purposes, forced labour, illegal adoptions, early and forced marriage, and body part trafficking.

\section{Methodology}

Missing persons, and more particularly missing children, remains an understudied area of research in the South African context. 'Despite the fact that missing persons are a social phenomenon which encompasses vast areas of interest, relatively little is known about those who go missing, what happens to them while they are missing, and what can be done to prevent these incidents from occurring' (Missing Children Europe n.d.). There is next to no available 
South African literature on the subject, apart from a few studies on enforced disappearances during the Apartheid era (see for example, Sarkin 2015). This has the implication that high levels of uncertainty and ignorance abound about the subject matter and ultimately, that the problem is not well understood. Similar to the study of other social phenomena, methodological issues also accompany the study of missing children. As with the wider literature on violence against children, there is an apparent lack of 'systematic research into the scale and forms of violence experienced by children' (Richter et al. 2018) which extends beyond statistics.

Sources of data used in this article include, firstly, interviews from a larger study about human trafficking for sexual exploitation in South Africa (Van der Watt 2018) in which 120 multidisciplinary participants from the criminal justice system, NGOs, the sex trade and victims of human trafficking shared their lived experiences. Secondly, available statistics provided by the South African Police Service and Missing Children South Africa were incorporated. Here the lack of a centralised database that collates such cases, and disparate reporting structures, made the quest for reliable data very difficult. There was also an indication from those working in the field that not all cases are registered accordingly, which means that accurate disaggregated statistics remain elusive. Notwithstanding the lack of accurate disaggregated statistics on missing persons in South Africa, available data does allow us to analyse observable patterns pertaining to missing children and the phenomenon of the 'missing' missing in the South African context. This dearth of data has meant that our study is essentially exploratory in nature. We hope that our findings and suggestions will encourage further research into this field. In this article we employ an interpretivist approach to the study of missing children in South Africa. Interpretive research is 'based on the assumption that social reality is not singular or objective, but is rather shaped by human experiences and social contexts' (Research Methods for the Social Sciences n.d.). An interpretive paradigm frames research from the perspective of participants, as well as the researchers themselves as active actors in the field. Both authors are active members of the National Freedom Network (NFN), whilst the co-author (Van der Watt) has occupied the NFN case manager position since October 2011. The National Freedom Network is a network of people and organisations in South Africa, who work together against human trafficking, exchange information, and share resources. It allowed us to construct and interpret our understanding from available data and lived 
experiences as practitioners in the field of anti-trafficking in persons within a wider network of state and civil society stakeholders engaged in child protection. The data employed in this article is complemented from more than two decades' lived experience in this field, as well as previous research by the authors. An inevitable 'investment of the self' (Birks 2014:24) therefore required both authors to embrace the concept of reflexivity (Creswell 2013:226, 228), and the notion that our backgrounds, prior knowledge and biases are interconnected with the research, and influence data generation and its analysis.

\section{Literature Review}

While the issue of missing children features prominently in the media, available literature on missing persons is scant in the South African context. The paucity of literature suggests a major research, and potentially policy gap that this article attempts to highlight and tentatively address. Missing persons' literature in the South African context focuses on transitional justice and the role played by the Truth and Reconciliation Commission in locating and exhuming bodies of victims of the apartheid regime as part of a nation-building process (see Rousseau 2015; Sarkin 2015). Even within the larger framework of violence against children, the literature is largely silent on the issue of missing children. Seminal works by Mathews and Benevuti (2014) and Hsiao et al. (2018) examine the different forms of violence against children, such as sexual and interpersonal violence, neglect and cultural and traditional practices, and their socio-economic and health impacts, but fail to link any of these outcomes to the issue of why children go missing in South Africa. From a survey of available literature (Aronson 2011; Lakha 2012; Rousseau 2015; Sarkin 2015), it appears that prior to trafficking in persons gaining prominence amongst South African academics there wasn't any real attempt to examine the phenomenon of missing children. The study by Hattingh and Matthee (2011) on the use of social media (Facebook) to locate missing persons, including children, from a crowd-sourcing perspective remains the exception. Antitrafficking literature has delved into the issue of missing persons, and children, when considering the modus operandi of traffickers and profile of victims (see van Zyl \& Horne 2009; Van der Watt 2018).

In the international literature, missing children account for approximately two-thirds of all missing persons cases (Missing People: n.d.). Youth 
between the ages of 13 and 15 account for the majority of missing children, with more girls between the ages of 14 and 16 going missing than boys (Biehal, Mitchell \& Wade 2003; Rees 2011). According to Missing People (n.d.), 'Children and young people living in foster care or in a children's home were found to be three times more likely to go missing than young people living with their family (Rees \& Lee 2005: 12)'. This correlates with the literature on trafficking in persons as well.

The International Centre for Missing and Exploited Children (2015:2) claims that while missing children is a global issue, it lacks a global response. Indeed, there is no international consensus on how to define a missing child or investigate such cases (ibid.).

Missing children are rarely referred to in national legislation, although they often exist as a subset in the general description and typology of missing persons used in police regulations. Their definition is often derived from the definition of a child in combination with that of a missing person. In practice this implies that missing children are considered as those aged under 18, for whom no information can be found on their whereabouts, in conjunction with all other conditions that may apply to the national definition of a missing child (European Commission 2013:3).

Missing children fall into five broad categories: (i) endangered runaway; (ii) family abduction; (iii) non-family abduction; (iv) lost, injured or otherwise missing; and (v) abandoned or unaccompanied minor. Unaccompanied migrant children are a particularly vulnerable sub-population in the South African context (see for example, Anderson, Apland \& Yarrow 2017). Children who 'are away from home or care for lengthy periods of time and who live outside of key societal institutions such as family, education and other statutory services; who do not receive formal sources of support; and who are self-reliant and/or dependent upon informal support networks' (Smeaton 2005 cited in CEOP 2011: 10) are described as 'detached' in the literature. The normalisation of detachment means that they may not be reported missing, yet remain highly vulnerable individuals (Missing People n.d.). While Biehal et al. (2003) found that 60 percent of missing children had run away from home, Missing People (n.d.) suggest that the line between being forced to leave home and actively choosing to run away becomes blurred where children make 
conscious decisions to leave a violent or dangerous familial environment. This is supported by Rees and Lee (2005) who found that a quarter of children had been reported missing had been forced to leave their home. In addition, children are also at risk of going missing due to being groomed and trafficked for sexual exploitation. 'Vulnerable girls are particularly at risk of being groomed by older males who seek to gain their trust before committing sexual offences against them. Missing incidents often begin with, or are further exacerbated by relationships such as this' (CEOP 2011: 11 cited in Missing People n.d.). The ICMEC (2016) found an irrefutable connection between missing children and child exploitation often overlooked in the South African literature. A multi-country study found that the longer a child is missing, the greater the threat of a child being exposed to high risk activities, such as sexual exploitation, trafficking in persons, and prostitution; illegal or unsafe employment; involvement in criminal activity (both as a victim and as a perpetrator); substance abuse; risk of physical or sexual assault; and in some circumstances, death (ICEM 2016:iv). Depending on the amount of time a child has gone missing, it may also lead to a deterioration of physical and emotional health and a lack of education (ibid.). It was thus surprising for us to find little or no real connection in the available South African literature to the issue of missing children and these forms of violence so often perpetrated against them. Even the Optimus Study (2016) which created the first ever measurement of the prevalence of violence against children in South Africa failed to interrogate whether any children surveyed had gone missing. In the following section, we discuss our findings and the realities of missing children in South Africa.

\section{The Scope, Nature and Extent of Missing Children in South Africa}

The spotlight on missing children in South Africa gained prominence in the late 1980s and early 1990s after the widely publicised case of the six missing girls linked to Gert van Rooyen and Joey Haarhoff. Reports of an increase in children disappearing and reported missing appeared in the media, with some of the earliest known statistics reported in a newspaper article by Roos (1991:8) as 989 children (missing in 1988), 708 children (missing in 1989) and 2234 children (missing in 1990). It was, however, unclear as to whether these figures represented the number of children who were still missing at the time of Roos' 
(1991:8) publication. According to the Missing Persons Bureau of the South African Police Service (SAPS), as quoted by Mkize (2013), a child goes missing every six hours in South Africa, which amounts to approximately 1450 missing children every year. Mkize (2013) quotes Warrant Officer Dereck Reynecke of the SAPS Missing Persons Bureau who mentions limited resources as the greatest challenge to publishing cases of missing persons. He highlights that only three cases are broadcast a week on the SAPS' 'When Duty Calls' broadcasted on SABC 2 (South African Broadcasting Channel). This amounts to 150 cases per year being broadcast for the entire South Africa. Reynecke refers to more than 1900 reported cases of missing persons in Gauteng alone, which is indicative of a 'great shortfall' (Mkize 2013). Similarly, in 2015, SAFM reported a noteworthy increase in children being reported missing. Again, shortfalls in the capacity of SAPS to address these matters comprehensively were underscored (SAFM 2015). The past five years have seen a rapid increase in South Africans from all spheres of society who rely on social media platforms such as Facebook and Twitter to bring attention to a missing loved one, a missing child, or simply amplifying the call of others to help in the search of a missing person.

The July 2014 case of Zindie Ribbink, whose children, four-year-old twins Dean and Jenna, were moments away from being abducted, made headlines in the media. Closed Circuit Television (CCTV) footage of the incident was widely circulated in the public domain. It clearly showed an unknown man and women pushing a trolley with Zindie's children out of a shopping mall pharmacy, after which the two suspects were confronted by the mother. The suspects calmly walked away after the incident. The police did not immediately open a criminal case as the Ribbink family was told that insufficient evidence existed to validate a criminal investigation. Dale Ribbink, the husband of Zindie, subsequently took it upon himself to conduct an investigation and provided the SAPS with the CCTV footage and the registration number of the vehicle allegedly used by the suspects (Versluis 2014).

Attempted abductions of children as young as two years old were widely reported on during 2015, when a pattern was identified at shopping centres in Pretoria where numerous parents narrated their public confrontations with abductors in a bid to stop their children from being snatched (Meijer 2015: 2). Makhubu (2015:1) underscores the need for sexual gratification, retribution, poverty and human trafficking as the major factors that contribute 
to the high number of missing children. The problem of cases not being reported, and the concomitant fragmented understanding of the problem's actual scope, is also highlighted. Angie Motaung of Bana Ba Kae in Pretoria West, a Pretoria-based NGO that works to address the needs of children from poor communities, is quoted as stating that 'there could be as many as 1000 children missing from homes across the city...'. She makes a sobering claim that 'some parents had too much else to worry about than run to the police to report missing children, in particular those in their teens' (Makhubu 2015:1).

Scant attention has been given to the nexus between at least some incidents of human trafficking in South Africa and incidents of adults and children that have been reported as missing. This uncharted nexus 'begs to be interrogated' (Van der Watt 2015). Not all missing persons' incidents relate to cases of human trafficking, but many human trafficking cases are typically incidents where people are considered to be missing (see also Chatterjee 2015). There is usually an underlying reason why people go missing - they do not simply disappear. According to the Association of Chief Police Officers (2010: 11), missing persons' incidents can be considered as the accumulation of other issues at play. People who go missing due to a psychiatric or health condition (i.e. dementia), someone who unknowingly went missing as result of neglecting to call home, and people under the influence of a third party (abduction or murder) are but some of the constituents of missing persons reports. An adult person who leaves a family to start a new life or a child who runs away from home may be considered as voluntary incidents, whilst victims of trafficking may not trust authorities to provide assistance or may return to their traffickers as they fear their families may be harmed. Forced marriage, child abuse, domestic violence and sexual and labour exploitation have also been associated with people going missing (Alys, Massey \& Tong 2013:143).

In a study by Van der Watt (2018) into human trafficking for sexual exploitation in South Africa, experiences and concerns about the unexplored nexus between human trafficking and missing persons were widely shared by participants who work at the frontline of counter-trafficking efforts in South Africa. One participant from a prominent NGO working with missing persons in South Africa expressed that 'one can't separate missing children from human trafficking or missing individuals from human trafficking' and pointed out that ' until you find a missing individual you can't be sure that they weren't trafficked'. She warned against a reductionist response by authorities who consistently treats missing persons and human trafficking as two distinct issues 
and argues that it is 'important to not separate the two but to incorporate them even more' (Van der Watt 2018: 232-233). An investigator from South Africa's Directorate for Priority Crime Investigation (commonly referred to as the Hawks) agreed with this view and suggested that 'every case that comes through...to the Missing Person Bureau must be looked in light of human trafficking as well'. He states, 'not necessarily every girl runs away with her boyfriend' and warns that 'it could be that the person is trafficked' (Van der Watt 2018: 233). Participants also voiced concerns about the negative 'attitude' displayed by both the police and the media towards runaway children and the fact that these children are predisposed to trafficking as 'they're out on the streets' (Van der Watt 2018: 233). Another Hawks investigator also pointed to the intersection of adoption irregularities in South Africa with human trafficking and missing children. He explains:

What we found in a lot of the cases we actually went to the families and the mothers weren't even aware that the children were up for adoption. As far as they were concerned the children were missing (Van der Watt 2018: 233).

Participants in the study by Van der Watt (2018) shared a number of other experiences and concerns. These included the non-reporting of missing children by their families, the continued misperception by some police and members of the public of the 24 hour waiting period before a person is reported missing, and the role of corruption and official complicity in cases of missing children and child trafficking. A number of participants mentioned the widespread indifference by the South African Police Service towards the plight of families. In one example the Managing Director of a grassroots NGO referred to a specific South African township where the community 'learn to live with a new normal type of thing' due to the lack of response to incidents of missing children. Concerning children 'disappearing off the streets', he points to the futile attempts by community members who approach the police for assistance as 'they wouldn't respond' (Van der Watt 2018: 232). The emerging theme of a nexus between human trafficking and missing persons in the research by Van der Watt (2018) led him to request available statistics from the SAPS Missing Persons Bureau on the incidence of missing persons in South Africa. Available data for a 15 -year period on both missing adults and missing children (Table 1) were obtained and is presented below. 


\section{Table 1: Reported missing persons: 1 January 2000 to 31 December 2015}

\section{Adults}

Reported missing from 2000/01/01 to 2015/12/31 49346

Cancelled (found) from 2000/01/01 to 2015/12/31 25543

Unaccounted for or still missing

\section{3}

\section{Children (Under 18)}

Reported missing from 2000/01/01 to $2015 / 12 / 31$

14252

Cancelled (found) from 2000/01/01 to 2015/12/31

10295

Unaccounted for or still missing

Source: SAPS Bureau for Missing Persons (2016)

Unfortunately, a geographical breakdown of missing persons' cases was not available at the time statistics were obtained. Feedback from provincial offices, however, suggested the following ranking of provinces reporting incidences of missing persons (SAPS Bureau for Missing Persons 2016):

- Gauteng

- Western Cape

- KwaZulu-Natal

- Mpumalanga

- Eastern Cape

- North West

- Limpopo

- Free State

- Northern Cape

At the time of the request to the SAPS for missing persons' data, a process of 'cleaning up the database' was said to be underway. A physical audit was being conducted, with the assistance of Department of Home Affairs' data and other available data in order to get rid of especially old cases that might be obsolete 
on the system. Previously wanted persons and missing persons shared a database that mostly catered for wanted persons. Statistical reports were therefore not accurate concerning missing persons when extracted from the system. At the time data were received, SAPS were correlating statistics manually at the provincial offices (Van der Watt 2018: 103).

Missing Children South Africa is an NGO that assists the SAPS in finding missing persons and creating awareness. It was established in March 2007 in response to the kidnapping and brutal murders of Sheldean Human (7) and Anestacia Wiese (12) in an effort to assist and support families finding themselves in similar desperate situations (Missing Children South Africa, n.d.). Below (Table 2) are figures of cases reported to and recorded by Missing Children South Africa (and do not reflect all cases reported to SAPS):

\section{Table 2: Reported missing persons: 1 May 2017 - 30 April 2018}

\section{Adults}

Reported missing

200

Cancelled (found)

Unaccounted for or still missing

\section{2}

\section{Children (Under 18)}

Reported missing

Cancelled (found)

Unaccounted for or still missing
124

94

30

Source: Missing Children South Africa (2019)

Missing Children SA has a $75 \%$ success rate in finding children reported as missing to them. However, they did indicate that their success rate continued to decrease year on year, for reasons unknown to them. They hypothesized that this could be a result of fewer cases being reported directly to them or that fewer people are being found. In the case of children, their records show that $2 \%$ of missing children are found deceased (Missing Children SA 2019).

The table below offers a breakdown of missing persons per province provided by Missing Children South Africa. 
Monique Emser \& Marcel van der Watt

Table 3: Geographical Breakdown of Missing Persons

\begin{tabular}{|l|c|c|c|c|c|c|}
\hline \multirow{2}{*}{ Province } & \multicolumn{2}{|c|}{ Adults } & \multicolumn{2}{c|}{ Children } & \multicolumn{2}{c|}{ Cases Reported } \\
\cline { 2 - 7 } & Missing & Found & Missing & Found & Missing & Found \\
\hline Gauteng & 95 & 65 & 60 & 45 & 156 & 110 \\
\hline Western Cape & 66 & 43 & 37 & 33 & 103 & 76 \\
\hline KwaZulu Natal & 15 & 13 & 15 & 19 & 30 & 22 \\
\hline Free State & 2 & 2 & 1 & 1 & 3 & 3 \\
\hline Eastern Cape & 2 & 1 & 2 & 1 & 4 & 2 \\
\hline North West & 11 & 6 & 6 & 4 & 17 & 10 \\
\hline Limpopo & 2 & 2 & 1 & 0 & 3 & 2 \\
\hline Mpumalanga & 5 & 5 & 2 & 1 & 7 & 6 \\
\hline Northern Cape & 1 & 1 & 0 & 0 & 1 & 1 \\
\hline
\end{tabular}

Source: Missing Children South Africa (2019)

Missing children are grouped in the following categories (see reasons for disappearance in the table below):

Table 4: Categorisation of Missing Children Cases

\begin{tabular}{|l|c|}
\hline Category & $\begin{array}{c}\text { Cases Reported } \\
\text { (percentage) }\end{array}$ \\
\hline Crime & 27 \\
\hline Run-Aways & 94 \\
\hline Kidnappings & 19 \\
\hline Human Trafficking & 2 \\
\hline Mentally Challenged & 10 \\
\hline Lost & 2 \\
\hline
\end{tabular}

Source: Missing Children South Africa (2019)

Missing Children South Africa's statistics correlate with findings in the international literature. While the majority of missing children are classified as 'run-aways' having either left home willingly or through threat to their own safety, we see that $27 \%$ of missing children are also victims of crime. 
Internationally, runaways account for $57 \%$ of missing children. This suggests that there are potentially serious underlying reasons within families or communities why children run away. More research is required in the South African context in relation to violence against children and child protection to address this. $2 \%$ of recorded cases are the result of human trafficking. However, such statistics do not provide a full picture of reality as human trafficking is consistently subsumed and misidentified under a variety of crimes and social phenomena.

Below is the breakdown of the different ages of children reported to Missing Children South Africa (1 May 2016 - 30 April 2017):

Table 5: Breakdown of Missing Children by Age

\begin{tabular}{|l|c|}
\hline Age & Percentage of Cases Reported \\
\hline $0-6$ years & 17 \\
\hline $7-12$ years & 22 \\
\hline $13-17$ years & 85 \\
\hline
\end{tabular}

Source: Missing Children South Africa (2019)

The percentage of children that are reported missing per age bracket are similar to findings in the international literature (see Biehal et al. 2003). The majority of children who are reported as missing fall in the 13-17 year age group. However, the authors were not able to ascertain at the time of the writing the reasons why this may be so in the South African context.

The literature on violence against children in South Africa has repeatedly shown that African children bear the brunt of violent acts and abuse committed against them whether by family, community members, strangers or their peers (Hsiao et al. 2018; Mathews \& Benevuti 2014; Optimus Study 2016; Richter et al. 2018). Below is a breakdown of the racial distribution of children reported to Missing Children SA:

Table 6: Racial Distribution of Missing Children

\begin{tabular}{|l|l|l|l|}
\hline African & Coloured & Caucasian & $\begin{array}{l}\text { Other (Indian, } \\
\text { Asian) }\end{array}$ \\
\hline $31 \%$ & $19 \%$ & $45 \%$ & $4 \%$ \\
\hline
\end{tabular}


Surprisingly, 'white' or Caucasian children make up the majority of children reported missing. We were unable to ascertain whether this was a result of awareness of the organisation by parents or guardians of these children who chose to report their children missing to the NGO in addition to SAPS, or whether Caucasian children go missing at a higher rate than other racial groups. More research is required in this regard. As African children are overwhelmingly victims of violence against children, we hypothesise that these figures are skewed and reflect reporting tendencies rather than reality.

Van der Watt's findings (2018) go hand-in-hand with international experience:

[F]ew countries have legislation specific to missing children, and national strategies, when they do exist, vary from country to country. Even fewer countries have policies in place to facilitate data collection, and statistics, when available, can be inaccurate and unreliable due to: under-reporting/under-recognition; inflation; incorrect database entry of case information; and deletion of records once a case is closed. Without accurate information, it is difficult to fully understand the issue of missing children and begin to formulate effective solutions, leaving missing child cases under-addressed (ICEMC 2016: iv).

Drawing on the apparent connection between human trafficking and missing children in certain instances, a lack of political will to adequately address wider issues of violence against children is disquieting. As van Niekerk (n.d.) opines, 'although there is much 'speak' about the rights of children and legislation is fairly progressive, little attention is paid to implementation of child protection legislation, and social services to children and families remain under-funded and undervalued'. In addition, the theme of corruption has been highlighted by participants. For example, a member of a prominent NGO involved with missing children in South Africa voiced their concern with the high levels of corruption in the country and how this may deleteriously affect the profile of missing persons' and human trafficking cases (Missing Children South Africa 2019). Equally concerning is the lack of a centralised database exclusively for missing persons that allows for the identification of deceased or unidentified missing persons (ibid.). Statistics are not up-to-date. Similarly, in the case of children that have been missing for years, there are no resources available to 
produce a new 'reconstruction' sketch of what the child may now look like, or provide one where an unidentified deceased person has been found. This compounds issues in identifying missing children and adults after a number of years. The respondent also noted that the nexus between human trafficking and missing persons is a growing reality, and there needed to be more official assistance and cooperation between missing persons' NGOs and specialised police units, such as the Hawks, tasked with dealing with such complex cases (ibid.). The respondent felt that more open channels of communication would facilitate greater information sharing and resources that could be leveraged to locate and identify missing persons who may have been trafficked (ibid.).

\section{Discussion and Policy Recommendations}

Proper collection, collation, analysis and reporting of data is foundational to a holistic understanding of phenomena related to missing persons, such as human trafficking and other social ills in society. In fact, we are missing most of what is really out there when we take the immediate statistical appearance of these phenomena as the whole truth. When we accept only what we can consciously rationalise and count, our understanding of these problems in South Africa will be reduced to the most abject limitations. Data and statistics related to missing adults and children must be released annually in an aggregated form. This must include data which clearly specify the number of persons reported missing; the number of persons found; reason for, or circumstances of disappearance; circumstances under which the adult or child was found; age, gender and race of the missing adult or child; how many missing persons cases translated into police inquiries or criminal cases; what was the outcome of such police inquiries or criminal cases; geographical location or province where the persons went missing; geographical location or province where the person was found.

Over a period of 17 years, and in collective capacities, which include police investigator, case manager for the NFN, and expert witness in cases of human trafficking, Van der Watt has spoken and worked with many disillusioned trafficking victims, parents, family- and community members. Much of the disillusionment is levelled against the police system with complaints ranging from parents who would much rather sit and wait for a child or an adult to return, to those who opt to employ private investigators or use their own means to locate a person than experiencing the 'trauma' of 
engaging with a local police station. It is difficult to grasp the anguish of a parent who attempts to report a child missing, but are then misinformed by police officials that they have to wait 24 or 48 hours or are advised that they should return on the Monday when efforts are made to report missing people over the weekend.

Notwithstanding the wide-ranging concerns that have been raised regarding the reliability of South Africa's crime statistics (Africa Check 2014; Masiloane 2014; Gould, Burger \& Newham 2012; Altbeker 2005), it is the view of the authors that available statistics are not even remotely an accurate reflection of the state of affairs regarding missing adults and children in South Africa. Compounding this, and counterintuitive to this dilemma, is the fact that some parents, guardians, and community members don't report children or adults as missing since they themselves are sometimes complicit in such disappearances. Social insentience also manifests in the labelling of children as a 'problem child' and not bringing the issue of children (or adults) in need of care to the attention of authorities. Both the police and the community are therefore collectively responsible for the well-being and safety of the country's children.

In terms of international best practice, the following recommendations are suggested (adapted from ICMEC 2016):

- There should be national legislation with a definition of a 'missing child' (and not limited to abducted or kidnapped children as defined in other legislation).

- Existing reporting mechanisms should be consolidated and centralised. 'The reporting mechanism should be: available nationwide 24 hours a day, 7 days a week; free of charge; accessible to both children and adults; and staffed by properly-trained personnel' (ICMEC 2016). This means that police and other child protection organisations need to be trained and sensitised on the urgency required when reporting a missing child. Within the South African context, the institutional memory, skills and experience of organisations like Missing Children South Africa must be leveraged and inculcated in the broader response.

- Missing child investigations need to be immediate once the report is taken - even where the child is considered to be a 'runaway'. As 
detailed earlier in this article, missing, abducted and runaway children are at great risk to various forms of violence, including death. The first three hours once a child is abducted are vital for investigation, as abducted children who are murdered are typically murdered within this short time frame following their abduction.

- A comprehensive national database of missing and unidentified children, that is accessible, is of paramount importance (as highlighted by Missing Children South Africa).

- The case management system to organise and record case information should be separate from wanted persons - and deal exclusively with missing persons and children. Such a system should include as far as possible: biometric information, 'including DNA, fingerprints, and dental records, of missing children and their families for crossreference in cases where visual identification of the child may not be possible' (ICMEC 2016:3); mandatory review periods; and categorisation in terms of a risk assessment of 'missing children'. Capacity, training and resources are vital in this regard.

- Photo distribution system - already effectively used in South Africa by various NGOs who leverage social media and the media. This should be formalised in policy and legislation.

- Responses and investigative procedures: 'Any agency - law enforcement or NGO - that accepts reports of missing children should have policies or standard operating procedures in place outlining their response to reports of missing children and investigative procedures. These include, but are not limited to:

- In-taking a report of a missing child, including what immediate actions the individual recording the report should take;

- Interviewing suspects, family members, friends, and witnesses;

- Developing the investigative strategy;

- Identifying the resources needed and determining available resources to search for the missing child;

- Collecting and managing forensic evidence;

○ Devising special procedures for children missing abroad; 
○ Determining how and when to activate response protocols; and

- Managing media involvement.

- Essential personnel should be trained regularly on these responses and procedures' (ICMEC 2016:4).

- Formal agreements need to be in place between agencies involved in missing children investigations and child protection.

- There is a need for community engagement programmes to educate the public on missing children and linked issues.

- Rapid emergency alert system, similar to that of the Amber alert system $^{6}$ in the United States for the most serious cases.

- A prevention framework linked to a strategy to prevent and combat violence against children.

The persistent call for a specialised, trained, and intelligence-driven counter human trafficking unit in South Africa has yet to be taken seriously. Such a unit can be employed to map the 'missing' missing phenomenon in South Africa through an analysis of current and historical missing children reports, and establishing, where present, linkages between circumstances of disappearance, and the modus operandi of known predators and human trafficking networks. Moreover, the monitoring of online platforms for both the identification of missing children and incidents of child trafficking becomes critical as 'available technologies gives perpetrators new avenues to groom and exploit children' (ECPAT International 2019).

In reconfiguring South Africa's approach to the 'missing' missing by government, policymakers, researchers, carers and criminal justice actors, valuable insights can be gleaned from Moloney's (2015: 28) sociological

6 'The AMBER Alert System began in 1996 when Dallas-Fort Worth broadcasters teamed with local police to develop an early warning system to help find abducted children. AMBER stands for America's Missing: Broadcast Emergency Response and was created as a legacy to 9-year-old Amber Hagerman, who was kidnapped while riding her bicycle in Arlington, Texas, and then brutally murdered' (U.S. Department of Justice, n.d.). 
perspective and the exploration of human trafficking as a diamond with multiple facets. Moloney's (2015: 28) insights, when applied to missing persons, would mean that each time the issue is picked up, discussed and analysed, it should be flipped over, turned around, and rotated to reveal and inspect a new facet. Heed should be taken against approaching South Africa's missing children, and by extension, missing persons, as a slippery annexure to the rest of the country's abuse, violence and social ills discourse. The multiple and interrelated facets of the problem must be appreciated and analysed, whilst political will is summoned to the solution-creation table.

Acknowledgement: Marcel van der Watt acknowledges the funding received from the University of South Africa's College Research and Innovation Committee (CRIC) that contributed to the research.

\section{References}

Africa Check 2014. South Africa's Official Crime Statistics for 2013/2014. Available at: https://africacheck.org/factsheets/factsheet-south-africasofficial-crime-statistics-for-201314/ (Accessed on 16 May 2016.)

Altbeker, A. 2005. The Dangers of Data: Recognising the Limitations of Crime Statistics. SA Crime Quarterly 14,December: 29 - 36.

Alys, L., K. Massey \& S. Tong 2013. Investigative Decision Making: Missing

People and Sexual Offences, Crossroads to an Uncertain Future. Journal of Investigative Psychology and Offender Profiling 10: 140 - 154. https://doi.org/10.1002/jip.1382

Anderson, K., K. Apland \& E. Yarrow 2017. Unaccompanied and

Unprotected: The Systemic Vulnerability of Unaccompanied Migrant

Children in South Africa. In Liefard, T. \& J. Sloth-Nielson (eds.): The United Nations Convention on the Rights of the Child: Taking Stock of 25 Years and Looking Ahead. Leiden: Brill-Nijhoff. https://doi.org/10.1163/9789004295056 020

Aronson, J.D. 2011. The Strengths and Limitations of South Africa's Search for Apartheid-Era Missing Persons. International Journal of Transitional Justice. https://doi.org/10.1093/ijtj/ijr013

Association of Chief Police Officers 2010. Guidance on the Management, Recording and Investigation of Missing Persons. $2^{\text {nd }}$ Edition. Wyboston: National Policing Improvement Agency. 
Balke, E. 2002. Trauma and Conflict. Development Studies Institute, London School of Economics and Political Science. Working Paper Series No. 0237. Available at:

http://www.lse.ac.uk/internationaldevelopment/pdf/wp/wp37.pdf

Birks, M. 2014. Practical Philosophy. In Mills, J. \& M. Birks 2014. Qualitative Methodology: A Practical Guide. London: Sage.

Centre for the Study of Violence and Reconciliation (CSVR) 2009. Why does

South Africa have such high rates of violent crime? Supplement to the

Final Report of the Study on the Violent Nature of Crime in South Africa.

Available at: https://www.csvr.org.za/docs/study/7.unique_about_SA.pdf Child Exploitation and Online Protection Centre (CEOP) 2011. Out of Mind, Out of Sight: Breaking Down the Barriers to Child Sexual Exploitation: Executive Summary. London: CEOP. Available at:

https://www.norfolklscb.org/wp-content/uploads/2015/03/ExecutiveSummary-CEOP-Thematic-Assessment.pdf

Chatterjee, P. 2015. All Missing Cases are not Human Trafficking but all Human Trafficking are Missing Cases: A Critical Analysis. Russian Journal of Sociology 1,1: 4 - 11. https://doi.org/10.13187/rjs.2015.1.4

Creswell, J.W. 2013. Qualitative Inquiry and Research Design: Choosing amongst Five Approaches. $3^{\text {rd }}$ Edition. Los Angeles, CA: Sage.

ECPAT International 2019. The Landscape of Sexual Exploitation of Children in South Africa. Bangkok: ECPAT International. Available at: https://www.ecpat.org/wp-content/uploads/2019/10/Landscape-of-

Sexual-Exploitation-of-Children-in-South-Africa-ECPAT-research-

October-2019.pdf

European Commission 2013. Missing Children in the European Union Mapping, Data Collection and Statistics. European Union: ECORYS Nederland BV. Available at:

http://missingchildreneurope.eu/Portals/0/Docs/1709_missing_children_ study 2013 en original 1.pdf

ER Services n.d. Chapter 12 Interpretive Research. Research Methods for the Social Sciences. Available at: https://courses.lumenlearning.com/sunyhccc-research-methods/chapter/chapter-12-interpretive-research/

Gould, C. 2018. Crime Stats: South Africa is at War with Itself. ISS Today, Daily Maverick. 12 September. Available at:

https://www.dailymaverick.co.za/article/2018-09-12-crime-stats-southafrica-is-at-war-with-itself/ 
Gould, C., J. Burger \& G. Newham 2012. The SAPS Crime Statistics: What They Tell Us - and What They Don't. SA Crime Quarterly 42, December: $3-12$.

Hall, K. \& W. Sambu 2018. Demography of South Africa's Children. South African Child Gurage. Available at: http://www.ci.uct.ac.za/sites/default/files/image_tool/images/367/Child Gauge/South_African_Child_Gauge_2018/Chapters/demography\%20of \%20South\%20Africa\%27s\%20children.pdf

Hamber, B. \& S. Lewis 1997. An Overview of the Consequences of Violence and Trauma in South Africa. Research Report Written for the Centre for the Study of Violence and Reconciliation, June. Available at: https://www.csvr.org.za/publications/1778-an-overview-of-theconsequences-of-violence-and-trauma-in-south-africa

Harris, B. 2003. Spaces of Violence, Places of Fear: Urban Conflict in Postapartheid South Africa. Paper presented on the Conflicts and Urban Violence panel, Foro Social Mundial Tematico, Cartagena, Colombia, 1620 June 2003.

Hattingh, M.J. \& M.C. Matthee 2011. Using Facebook to Find Missing Persons: A Crowd-sourcing Perspective. Berlin \& Heidelberg. SpringerVerlag: Available at:

https://www.researchgate.net/profile/Machdel_Matthee/publication/3063 63777_Using_Facebook_to_Find_Missing_Persons_A_CrowdSourcing_Perspective/links/5aa14e130f7e9badd9a430e4/UsingFacebook-to-Find-Missing-Persons-A-Crowd-Sourcing-Perspective.pdf Hsiao, C., D. Fry, C.L. Ward, G. Ganz, T. Casey, X. Zheng \& X. Fang 2018. Violence against Children in South Africa: The Cost of Inaction to Society and the Economy. BMJ Global Health 3,1. Available at:

http://dx.doi.org/10.1136/bmjgh-2017-000573

International Centre for Missing \& Exploited Children (ICMEC) 2015. Model Missing Child Framework. Available at: https://www.icmec.org/modelmissing-child-framework/

ICMEC n.d. The Definition of 'Missing'. Available at:

https://www.icmec.org/global-missing-childrens-center/the-definitionof-missing/

Kabwete, C.M. 2018. Towards Justice and Reconciliation in Post-conflict Countries: Meaningful Concepts and Possible Realities. African Journal on Conflict Resolution 2018, 1. Available at: 
https://www.accord.org.za/ajcr-issues/towards-justice-andreconciliation-in-post-conflict-countries/

Kadir, A., S. Shenoda, J. Goldhagen, S. Pitterman \& Section on International Child Health Executive Committee, 2017 - 2018. 2018. The Effects of Armed Conflict on Children. Pediatrics. November, e20182586; DOI: https://doi.org/10.1542/peds.2018-2586

Kynoch, G. 2005. Crime, Conflict and Politics in the Transition-era in South Africa. African Affairs 104/416: 493 - 514. DOI: 10.1093/afraf/adi009. Available at: https://doi.org/10.1093/afraf/adi009

https://www.jstor.org/stable/3518726?seq=1\#page_scan_tab_contents

Lakha, K. 2012. A Day in the Life of the Missing Persons Task Team. Quest 8, 2: $16-17$.

Makhubu, N. 2015. Missing Kids Tragedy: Poverty, Human Trafficking behind Children Disappearing without Trace. Pretoria News 5 June: 1.

Makoae, M. 2014. Safeguarding South Africa's Future: The Need for Integrated Prevention Programmes in Child Protection. Policy Brief. Human Security Research Council. Available at:

http://www.hsrc.ac.za/en/research-outputs/view/7018

Mathews, S. \& P. Benevuti 2014. Violence against Children in South Africa: Developing a Prevention Agenda. South African Child Gauge. Available: http://www.ci.uct.ac.za/sites/default/files/image_tool/images/367/publica tion/2014/ChildGauge2014_preventionagenda.pdf

Mathews, S., R. Govender, G. Lamb, F. Boonzaier, A. Dawes, C. Ward, S. Duma, L. Baraecke, G. Warton, L. Artz, T. Meer, L. Jamieson \& R. Smith 2016. Towards a More Comprehensive Understanding of the Direct and Indirect Determinants of Violence against Women and Children in South Africa with a View to Enhancing Violence Prevention. Cape Town: Safety and Violence Initiative: University of Cape Town. Available at: http://www.savi.uct.ac.za/sites/default/files/image_tool/images/168/UCT \%20SaVI Towards\%20a\%20More\%20Comprehensive\%20Understandi ng\%20of\%20the\%20Direct\%20and\%20Indirect\%20Determinants\%20of \%20Violence\%20against $\% 20$ Women $\% 20$ and $\% 20$ Children $\% 20 \mathrm{in} \% 20$ So uth\%20Africa_2016.PDF

Meijer, K. 2015. Reports of Attempts to Snatch Children Rising. Centurion Rekord 6 November 2015.

Missing Children Europe n.d. Missing Children Publication Hub. Available at: http://missingchildreneurope.eu/catalog/documentid/421 
Missing Children South Africa 2019. Missing Persons' Statistics. Email Correspondence.

Missing People n.d. Missing People Information Fact Sheet: Missing Children and Young People.

Mkize, V. 2013. 45000 Kids prostituted in SA. The Star 24 May. Available at: http://www.iol.co.za/news/crime-courts/45-000-kids-prostituted-in-sa-

1521439

(Accessed on 3 May 2016.)

Mujawayo, E. 2014. 'You are not crazy, your situation was'. Psychosocial Support. Development and Cooperation 23 September. Available at: https://www.dandc.eu/en/article/dealing-trauma-essential-peacebuildingpost-conflict-countries

Nxumalo, M. \& R. Philander 2017. Child Abuse Stats Shock. Daily News 18 August. Available at: https://www.iol.co.za/dailynews/child-abuse-statsshock-10831327

Optimus Study 2016. Optimus Study South Africa: Technical Report. Sexual Victimisation of Children in South Africa. Final Report of the Optimus Foundation Study: South Africa. UBS Optimus Foundation. Available at: www.optimusstudy.org

Pearce, J., R. McGee with J. Wheeler 2011. Violence, Security and Democracy: Perverse Interfaces and their Implications for States and Citizens in the Global South. IDS Working Paper 357. February. Brighton: Institute of Development Studies, University of Sussex. Available at: https://onlinelibrary.wiley.com/doi/pdf/10.1111/j.20400209.2011.00357_2.x;

https://doi.org/10.1111/j.2040-0209.2011.00357 2.x

Research Methods for the Social Sciences n.d. Chapter 12: Interpretive Research. Lumen. Available at: https://courses.lumenlearning.com/atdherkimer-researchmethodsforsocialscience/chapter/chapter-12interpretive-research/

Richter, L.M., S. Mathews, J. Kagura \& E. Nonterah 2018. A Longitudinal Perspective on Violence in the Lives of South African Children from the Birth to Twenty Plus Cohort Study in Johannesburg - Soweto. South African Medical Journal 108,3: 181 - 186. Available at: https://doi.org/10.7196/SAMJ.2018.v108i3.12661

Roos, M. 1991. Kinderverdwyning Styg Dramaties. [Child Disappearances Escalates Dramatically.] Beeld, 11 September: 8. 
Rousseau, N. 2015. Identification, Politics, Disciplines: Missing Persons and Colonial Skeletons in South Africa. In Anstett, E. \& J-M. Dreyfus (eds.): Human Remains and Identification: Mass Violence, Genocide, and the 'Forensic Turn'. Manchester: Manchester University Press. https://doi.org/10.7228/manchester/9780719097560.003.0008

SAFM 2015. Child Kidnapping Remains a Problem in SA. The forum @ eight 13 May.

Sarkin, J. 2015. Dealing with Enforced Disappearances in South Africa (with a focus on the Nokuthula Simelane Case) and Around the World: The Need to Ensure Progress on the Rights to Truth, Justice and Reparations in South Africa. Speculum Juris 29, 1. Available at:

http://specjuris.ufh.ac.za/dealing-enforced-disappearances-south-africa-

focus-nokuthula-simelane-case-and-around-world-need

Scheper-Hughes, N. \& P. Bourgois 2004. Introduction: Making Sense of Violence. In Scheper-Hughes, N. \& P. Bourgois (eds.): Violence in War and Peace: An Anthology. London: Wiley-Blackwell.

Seedat, M., A. van Niekerk, R. Jewkes, S. Suffla \& K. Ratele 2009. Violence and Injuries in South Africa: Prioritising an Agenda for Prevention. Lancet 374, 9694: 1011 - 1022. Available at:

https://doi.org/10.1016/s0140-6736(09)60948-x

Sibanda, R. 2019. Child Protection Week 2019. Politics Web. June. Available: https://www.politicsweb.co.za/opinion/child-protection-week-2019

Sibanda-Moyo, N., E. Khonje, M.K. Brobbey 2017. Violence against Women in South Africa: A Country in Crisis. Centre for the Study of Violence and Reconciliation. Available at: https://www.csvr.org.za/pdf/CSVRViolence-Against-Women-in-SA.pdf

Smith, J.A. \& M. Osborn 2015. Interpretative Phenomenological Analysis as a Useful Methodology for Research on the Lived Experience of Pain. British Journal of Pain February, 9,1: 41 - 42.

https://doi.org/10.1177/2049463714541642 Available at: https://www.ncbi.nlm.nih.gov/pmc/articles/PMC4616994/uff;

Social Trends Institute 2017. World Family Map 2017: Mapping Family Change and Child Well-being Outcomes. New York, Barcelona: Social Trends Institute.

South African Human Rights Commission 2018. Unpacking the Gaps and Challenges in Addressing Gender-based Violence in South Africa. Research Brief. Available at: 
https://www.sahrc.org.za/home/21/files/SAHRC\%20GBV\%20Research $\%$ 20Brief\%20Publication.pdf

South African Police Service (SAPS) Bureau for Missing Persons 2016.

Missing Persons' Statistics. Private Email Message to M. Van der Watt.

(21 November 2016.)

United States Department of Justice: Office of Justice Programs n.d. AMBER

Alert. America's Missing: Broadcast Emergency Response. Available at: https://www.amberalert.gov/faqs.htm

Van der Watt, M. 2015. Human Trafficking in South Africa: An Elusive Statistical Nightmare. The Conversation 16 July. Available at: http://theconversation.com/human-trafficking-in-south-africa-an-elusivestatistical-nightmare-43949

(Accessed on 19 December 2015.)

Van der Watt, M. 2018. Investigating Human Trafficking for Sexual Exploitation: From 'Lived Experiences' towards a Complex-systems Understanding. (Unpublished Ph.D. thesis). Pretoria: University of South Africa.

Van Niekerk, J. n.d. The Status of Child Abuse and Neglect Policy and Child Protection Practice in South Africa. Childline South Africa.

Available at:

https://www.childlinesa.org.za/wp-content/uploads/status-of-childabuse-and-neglect-law-and-policy-in-south-africa.pdf

Van Zyl, M. \& J. Horne 2009. A Policing Perspective on the Investigation Challenges of Child Trafficking in South Africa. Child Abuse Research in South Africa 10, 2: 10 - 4.

Versluis, J-M. 2014. Polisie Weier Klag na 2-ling byna Ontvoer is. [Police Refuse Case after Twins were almost Kidnapped.] Beeld 11 July. Available at: http://www.netwerk24.com/Nuus/Polisie-weier-klag-na-2ling-byna-ontvoer-is-20140711?mobile=true (accessed 3 May 2016).

Vujovic, M. 2008. Experiencing Violence: A Phenomenological Study of Adolescent girls. Unpublished $\mathrm{PhD}$ thesis. University of Johannesburg. Wessells, M. 2008. Trauma, Peacebuilding and Development: An Africa Region Perspective. Paper presented at the Trauma, Development and Peacebuilding Conference, New Delhi, India. September 9-11. Hosted by International Conflict Research Institute and International Development Research Centre. Available at: http://www.incore.ulst.ac.uk/pdfs/IDRCwessels.pdf 
World Health Organization n.d. Definition and Typology of Violence. Violence Prevention Alliance. Available at:

https://www.who.int/violenceprevention/approach/definition/en/

\author{
Monique Emser \\ International and Public Affairs \\ School of Social Sciences \\ University of KwaZulu-Natal \\ EmserM@ukzn.ac.za
}

Marcel van der Watt

Police Practice

School of Criminal Justice

University of South Africa

vdwatm1@unisa.ac.za 